\title{
Microstructural Characterization of Semi-Interpenetrating Polymer Networks by Positron Lifetime Spectroscopy
}

Jag J. Singh, Ruth H. Pater, and Abe Eftekhari 



\section{Microstructural Characterization of Semi-Interpenetrating Polymer Networks by Positron Lifetime Spectroscopy}

Jag J. Singh and Ruth H. Pater

Langley Research Center $\bullet$ Hampton, Virginia

Abe Eftekhari

Hampton University • Hampton, Virginia 
Available electronically at the following URL address: http://techreports.larc.nasa.gov/lurs/ltrs.html

Printed copies available from the following:

NASA Center for AeroSpace Information 800 Elkridge Landing Road

Linthicum Heights, MD 21090-2934

(301) 621-0390
National Technical Information Service (NTIS)

5285 Port Royal Road

Springfield, VA 22161-2171

(703) $487-4650$ 


\section{Symbols and Abbreviations}

\begin{tabular}{ll}
$A$ & parallel plate area \\
BTDE & benzophenone tetracarboxylic acid \\
$C$ & capacitance \\
C & structural constant \\
$d$ & spacing between plates (sample thickness) \\
FMW & formulated molecular weight \\
$f$ & free volume fraction \\
$I_{i}$ & intensity of $i$ th component \\
NE & 5-norbornene-2,3-dicarboxylic acid \\
NMP & N-methyl pyrrolidone \\
ODA & oxydianiline \\
ODPA & oxydiphthalic anhydride \\
PA & phthalic anhydride \\
PAS & Positron Annihilation Spectroscopy \\
$R$ & radius of microvoid \\
S-IPN & Semi-Interpenetrating Polymer Network \\
$V_{f}$ & free volume cell size associated with $i$ th component \\
v/o & percent by volume \\
w/o & percent by weight \\
$w_{i}$ & weight fraction of component $i$ \\
$\alpha$ & intermolecular chain interaction constant \\
$\beta$ & molecular chain overlap parameter \\
$\varepsilon$ & dielectric constant \\
$\varepsilon_{\text {air }}$ & dielectric constant of air \\
$\varepsilon_{R}$ & dielectric constant of sample with zero free volume \\
$\rho$ & density of S-IPN sample \\
$\tau_{i}$ & lifetime of $i$ th component \\
Subscripts: & \\
comp & computed \\
exp & experimental \\
\hline
\end{tabular}





\begin{abstract}
Thermoset and thermoplastic polyimides have complementary physical and mechanical properties. Whereas thermoset polyimides are brittle and generally easier to process, thermoplastic polyimides are tough but harder to process. A combination of these two types of polyimides may help produce polymers more suitable for aerospace applications. Semi-Interpenetrating Polymer Networks (S-IPN) of thermoset $L_{L R C}^{T M_{-} R P 46}$ and thermoplastic LaRC TM-IA polyimides were prepared in weight percent ratios ranging from 100:0 to 0:100. Positron lifetime measurements were made in these samples to correlate their free volume features with physical and mechanical properties. As expected, positronium atoms are not formed in these samples. The second lifetime component has been used to infer the positron trap dimensions. The "free volume" goes through a minimum at a ratio of about 50:50, and this suggests that S-IPN samples are not merely solid solutions of the two polymers. These data and related structural properties of the S-IPN samples are discussed.
\end{abstract}

\section{Introduction}

Increasing emphasis on easy processing and good fracture toughness of composite matrix resins for aerospace structural applications has provided an impetus to develop high performance Semi-Interpenetrating Polymer Networks (S-IPN's). Thermosetting polyimides are generally easy to process but are brittle. In contrast, thermoplastic polyimides are tough but difficult to process. Combining them would be expected to lead to tough and easy to process high performance S-IPN's. (See ref. 1.) Based on this concept, we have synthesized a series of S-IPN's by combining LaRC ${ }^{\mathrm{TM}}-\mathrm{RP} 46$ with LaRC $^{\mathrm{TM}}$-IA in various weight ratios.

The morphology of polymeric materials strongly affects their physical and mechanical properties. However, no reliable techniques are currently available for detailed morphological studies of these materials, particularly at the molecular level, mainly because of the rather intractable nature of the interpenetrating polymer networks. In this investigation, Positron Annihilation Spectroscopy (PAS) was employed to directly measure free volume cell sizes $V_{f}$ in seven S-IPN systems that contained weight percent ratios of 100:0, 75:25, 65:35, $50: 50,35: 65,25: 75$, and $0: 100$ of $\mathrm{LaRC}^{\mathrm{TM}}-\mathrm{RP} 46$ and LaRC $^{\mathrm{TM}}$-IA polyimides. The experimental techniques, results of various measurements, and correlations between $V_{f}$ and physical and mechanical properties are discussed in this paper.

\section{Experimental Techniques}

\section{Sample Preparation}

$\mathrm{LaRC}^{\mathrm{TM}}$-RP46 is a thermosetting polyimide prepared from the dimethyl ester of 3,3,4,4'-benzophenone tetracarboxylic acid (BTDE), 3,4'-oxydianiline $\left(3,4^{\prime}\right.$ ODA) and the monomethyl ester of 5-norbornene-2,3- dicarboxylic acid (NE). NE is an end-capping agent through which cross-linking reactions occur. The formulated molecular weight (FMW) of this polymer was arranged to be $1500 \mathrm{~g} / \mathrm{mole}$. Figure 1 shows the synthesis of $\mathrm{LaRC}^{\mathrm{TM}}$-RP46 prepolymer. $\mathrm{LaRC}^{\mathrm{TM}}$-IA is a thermoplastic polyimide, prepared from 4,4'-oxydiphthalic anhydride (ODPA), 3, $4^{\prime}$-ODA, and 8 mole percent of phthalic anhydride. Phthalic anhydride acts as a nonreactive end group to control the molecular weight of the polymer. Figure 2 shows the synthesis of $\mathrm{LaRC}^{\mathrm{TM}}-\mathrm{IA}$ polyamic acid, which is a precursor of the polyimide. The formulated molecular weight of this polymer was controlled to be $9000 \mathrm{~g} / \mathrm{mole}$.

Both $\mathrm{LaRC}^{\mathrm{TM}}-\mathrm{RP} 46$ and $\mathrm{LaRC}^{\mathrm{TM}}-\mathrm{IA}$ polyimides were recently developed at the Langley Research Center. (See refs. 2 and 3.) Their outstanding physical and mechanical properties show promise for a wide variety of aerospace and nonaerospace applications. Both polymers are now commercially available.

The S-IPN's were prepared from LaRC ${ }^{\text {TM }}$-RP46 oligomer and LaRC ${ }^{\mathrm{TM}}$-IA polyamic acid. Typically, the LaRC $^{\text {TM }}$-RP46 oligomers were dissolved in a minimum amount of N-methyl pyrrolidone (NMP) at $70^{\circ} \mathrm{C}$ and then added to the LaRC ${ }^{\text {TM }}$-IA polyamic acid solution in NMP. The mixture was stirred for 1 hour at room temperature and then heated for 2 hours at $60^{\circ} \mathrm{C}$ in a vacuum oven; this was followed by heating for 2 hours each at $200^{\circ} \mathrm{C}$ and $250^{\circ} \mathrm{C}$. This heating sequence produced B-staged molding powder. Approximately 5.0 gram of the B-staged molding powder was placed in a 3.175 - by $3.175-\mathrm{cm}$ stainless-steel mold, which was preheated with a Dexter Frekote release agent. The mold was heated to $290^{\circ} \mathrm{C}$ at a pressure of $13.8 \mathrm{MPa}$ and then held for 1 hour at $325^{\circ} \mathrm{C}$. Because the LaRC ${ }^{\mathrm{TM}}-\mathrm{IA}$ material had greater resin flow than the S-IPN's and $\mathrm{LaRC}^{\mathrm{TM}}-\mathrm{RP} 46$, it was cured at $355^{\circ} \mathrm{C}$ for 1 hour under a pressure of $2.07 \mathrm{MPa}$. 
The thickness of the resin prepared for PAS measurements was controlled by using a $0.3302-\mathrm{cm}$ spacer inserted in the mold. Much thicker samples were prepared for moisture absorption and dielectric constant determinations. Figure 3 shows the synthesis sequence of the S-IPN materials.

\section{Measurements}

Positron lifetime measurements. Positron lifetime measurements were made with a standard fast-fast coincidence measurement technique. Samples were cut in the form of 2.5 - by 2.5 - by $0.25-\mathrm{cm}$ coupons. A $25-\mu \mathrm{Ci}$ positron source was prepared by depositing $\mathrm{Na}^{22} \mathrm{Cl}$ solution on a 2.54- $\mu$ m-thick Du Pont Kapton foil folded on itself. The positron source was sandwiched between the test coupons, and the spectra were accumulated for 24 hours. This counting period produced a total of about $10^{6}$ counts in each spectrum. The time resolution of the lifetime system was about $280 \mathrm{psec}$. All measurements were made at room temperature in dry samples. The lifetime spectra were analyzed with the PATFIT program (ref. 4).

Saturation moisture measurements. Each of the cured resin specimens, having sizes of approximately 2.5 by 2.5 by $0.4 \mathrm{~cm}$, were immersed in water at $90^{\circ} \mathrm{C}$. Their weights were monitored continually, over a period of several days, until they stabilized.

Density measurements. The density of each sample was measured by a standard water displacement technique.

Dielectric constant measurements. The desiccated S-IPN samples were configured into the form of parallel plate condensers whose capacitances were measured with an impedance analyzer at 10 and $13 \mathrm{MHz}$. The dielectric constants were then computed on the basis of the measured values of the capacitances and the thicknesses of the samples.

\section{Experimental Results}

\section{Positron Lifetime Measurements}

All positron lifetime spectra were acquired under identical conditions with frequent time resolution checks with a $\mathrm{Co}^{60}$ gamma radiation source. All spectra were resolved into three components, by using the PATFIT program (ref. 4). However, the intensity of the third component $\left(I_{3}\right)$ was $\leq 0.50$ percent for all samples. It was, therefore, attributed to the source itself. Figures 4 to 6 illustrate typical positron lifetime spectra in the S-IPN samples. The lifetime results in these samples are summarized in table I. Note that the second lifetime component $\left(\tau_{2}\right)$ is the dominant component in all S-IPN samples. This component corresponds to the positrons trapped in potential defects or microvoids in the samples. These microvoids result from packing inhomogeneity of the molecular chains. The sizes of these microvoids are too small for the formation and localization of positronium atoms. However, free positrons can be trapped at these sites with subsequent annihilation. The radii of the microvoids $R$ in nanometers and the trapped positron lifetimes $\tau_{2}$ in nanoseconds are related as follows:

$$
\frac{1}{3 \tau_{2}}=\left(1-\frac{R}{R+\Delta R}+\frac{1}{2 \pi} \sin 2 \pi \frac{R}{R+\Delta R}\right)
$$

where $\Delta R=0.1659 \mathrm{~nm}$ (ref. 5).

Equation (1) differs from the conventional model (ref. 5) for the positronium-forming media in having $1 / 3 \tau_{2}$ instead of $1 / 2 \tau_{3}$ as the term on the left-hand side. This form of the equation was dictated by the following considerations:

1. The positron annihilation in polyimides differs considerably from that observed in most other polymers; it proceeds from the free or trapped positron states without the formation of positronium atoms.

2. Positron lifetime spectra in all of the polyimides investigated in this laboratory exhibit only two lifetime components.

The shorter lifetime $\tau_{1}$ ranges from 100 to $300 \mathrm{psec}$ and arises from free positron annihilation. The longer lifetime $\tau_{2}$, whose value ranges from 400 to $900 \mathrm{psec}$, has been reportedly associated with the positrons trapped at defect sites (microvoids). (See refs. 6 and 7.) Recently, it has been reported in reference 8 that $1 / 2 \tau_{3}$ for localized positronium can be paralleled by $1 / n \tau_{2}$ for localized positrons for determining the microvoid size. The maximum value of $1 / n \tau_{2}$, which corresponds to the minimum dimension of the microvoid, is of the order of 1 . Thus, for $\tau_{2} \approx 0.4 \mathrm{nsec}, 1 / 3 \tau_{2}$ becomes the appropriate form. The microvoid volume $V_{f}$ is calculated from (4/3) $\pi R^{3}$. Free volume fractions $f$ in the test samples were calculated as follows:

$$
f=\mathrm{CI}_{2} V_{f_{2}}
$$

where $\mathrm{C}$ is a structural constant and $I_{2}$ is the intensity of the trapped positron lifetime component. The structural constant $\mathrm{C}$ was assumed to have the same value for all $\mathrm{S}$-IPN samples investigated. This assumption is justifiable since the chemical structures of the $\mathrm{LaRC}^{\mathrm{TM}}-\mathrm{RP} 46$ and LaRC ${ }^{\mathrm{TM}}$-IA polyimides are similar. The values of $I_{2} V_{f_{2}}$ for all the samples are summarized in table II. 


\section{Density and Saturation Moisture Measurements}

The values of density and saturation moisture content of the various samples are presented in table III. The densities, as a function of the $\mathrm{LaRC}^{\mathrm{TM}}$-RP46 concentration in the samples, are illustrated in figures 7 and 8 .

A quick reference to tables II and III shows that the free volume fractions $\mathrm{CI}_{2} V_{f_{2}}$ bear no direct correlations with the saturation moisture contents of the S-IPN samples. This result is not surprising because water can enter the LaRC ${ }^{\mathrm{TM}}$-RP46 polymer chemically as well as physically. This hydration of the thermosetting component makes it difficult to equate the saturation moisture contents of the S-IPN samples with their free volume fractions. However, the hydration of $\mathrm{LaRC}^{\mathrm{TM}}-\mathrm{IA}$ is miniscule and may be neglected. All entry of water is physical, filling up the available free volume in it. By equating the percent by volume (v/o) occupied by the saturation moisture content in it with its $\mathrm{CI}_{2} V_{f_{2}}, \mathrm{C}$ was calculated to be 0.0058 . This value of $\mathrm{C}$ was used to calculate free volume fractions $f$ in all S-IPN samples, and these results are summarized in table IV.

\section{Dielectric Constant Measurements}

The desiccated S-IPN samples were configured into the form of parallel-plate condensers whose capacitances $C$ were measured by using an impedance analyzer at $10 \mathrm{MHz}$ :

$$
C=\varepsilon \frac{A}{4 \pi d}
$$

where

$\varepsilon \quad$ dielectric constant

A parallel plate area (kept same for all samples)

$d \quad$ spacing between plates (equivalent to thickness of S-IPN samples)

Equation (3) can be rearranged as follows:

$$
C d=\varepsilon\left(\frac{A}{4 \pi}\right)=\varepsilon(\text { Constant })
$$

that is

$$
C d \propto \varepsilon
$$

Because the sample thicknesses $d$ could not be made exactly equal, we decided to use $C d$ as a measure of dielectric constant $\varepsilon$, in arbitrary units, throughout the text of this paper. For reference purposes, the actual value of $\varepsilon$ for LaRC ${ }^{\mathrm{TM}}$-RP46 sample has been measured to be $3.13 \pm 0.03$ at $10 \mathrm{Mhz}$. The values of dielectric constants of other samples can be calculated by simply multiplying $C d$ values by $3.13 / 8.90=0.352$. The measured values of $C d$ are included in table IV.

\section{Discussion}

As shown in figure 3(a), the cured thermosetting and the thermoplastic components have almost the same molecular weights in their repeating units (486 versus 458). Thus, their weight ratio is essentially equal to their molar ratio. Figure 3(b) shows the prevailing concept of mutual interpenetration of the constituent polymers in the S-IPN's. The physical penetration would progressively increase until the constituent polymers reach a $50: 50$ composition where a maximum overlapping of the molecular chains would occur. Therefore, the S-IPN's would be expected to become gradually physically stronger until they reach a 50:50 composition. However, this linear concept does not take into account the interatomic (electrostatic) forces that would also maximize under the same conditions. The dipolar charge distribution in $\mathrm{LaRC}^{\mathrm{TM}}$-RP46 molecules would induce corresponding charge distribution in overlying IA molecules through a donor-acceptor type of mechanism, resulting in strong electrostatic bonding between them. The combination of the mechanical and electrostatic interactions would result in a nonlinear behavior, with minimum free volume cell size $V_{f_{2}}$ and free volume fraction $f$ at 50:50 composition, as evidenced in figures 9 and 10 .

Under these circumstances, the dielectric constant $\varepsilon$ of the S-IPN samples should change (ref. 9) with the sample composition as follows:

$$
\frac{1}{\varepsilon}=\frac{1-f}{\varepsilon_{R}}+\frac{f}{\varepsilon_{\text {air }}}
$$

where

f

$\varepsilon_{R} \quad$ dielectric constant of sample with zero free volume in it

$\varepsilon_{\text {air }} \quad$ dielectric constant of air

In previous studies (ref. 9), we have used saturation moisture content in polyimides as a measure of their free volume fractions. However, the thermosetting components of the S-IPN samples investigated here allow physical as well as chemical entry of water by forming hydrogen bonding with the carbonyl group of the benzophenone in their chains. This chemical entry invalidates the assumption of free volume equating with the saturation moisture content. The thermoplastic components ( $\mathrm{LaRC}^{\mathrm{TM}}$-IA), on the other hand, do not allow chemical entry of water in their chains. Therefore, the saturation moisture content of sample 1 (LaRC ${ }^{\mathrm{TM}}-\mathrm{RP} 46$ : $\mathrm{LaRC}^{\mathrm{TM}}$-IA; 0:100) has been used to calculate the structural constant $C$ needed to calculate the free volume fractions of the S-IPN samples on the basis of their $I_{2} V_{f_{2}}$ data. These results and related dielectric constant data are summarized in table $\mathrm{V}$ and illustrated in figures 11,12 , 
and 13. The agreement between the free volume model (eq. (5)) and the experimental data is reasonably good.

In the presence of both mechanical and electrostatic interactions between the constituent polymers, the density $\rho$ of an S-IPN sample can be written as follows:

$$
\rho=w_{1} \rho_{1}+w_{2} \rho_{2}+0.5 \alpha \beta\left(\rho_{1}+\rho_{2}\right)
$$

where

$$
\begin{aligned}
& w_{i} \quad \text { weight fraction of component } i ; w_{1}+w_{2}=1 \\
& \alpha \text { intermolecular chain interaction constant } \\
& \beta \quad \text { molecular chain overlap parameter }
\end{aligned}
$$

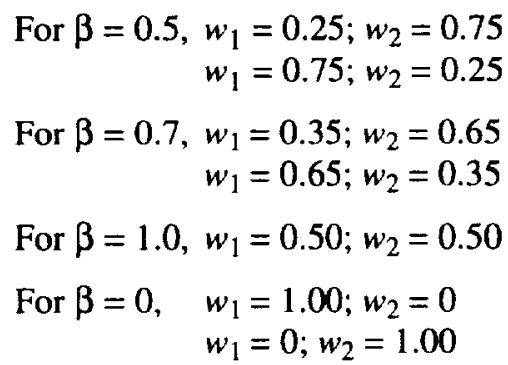

The least-squares fit of the experimental density values with the predictions of equation (6) gives $\alpha=0.0168$ \pm 0.0031 . Such a strong interaction constant between the LaRC ${ }^{\mathrm{TM}}$-RP46 and the LaRC ${ }^{\mathrm{TM}}$-IA molecular chains is consistent with the dipolar charge distribution at the carbonyl site in $\mathrm{LaRC}^{\mathrm{TM}}-\mathrm{RP} 46$ inducing an opposing dipole in LaRC ${ }^{\mathrm{TM}}$-IA chain overlying it. The experimental and the computed values of the densities for the various S-IPN samples are summarized in table VI. The agreement is reasonably good, except for the $25: 75$ S-IPN samples where the experimental value is about 1.9 percent too high, possibly due to processing anomalies. Figure 8 illustrates the comparison between the experimental and the computed values.

\section{Concluding Remarks}

Free volume characteristics of S-IPN samples synthesized from $\mathrm{LaRC}^{\mathrm{TM}}-\mathrm{RP} 46$ and $\mathrm{LaRC}^{\mathrm{TM}}-\mathrm{IA}$ polyimides were investigated. The experimental data indicate that these materials are not merely solid solutions of the constituent polymers. Their nonlinear characteristics dictate that both steric and electrostatic forces are needed to explain the observed relations between the free volume and dielectric constant and between the density and chemical composition of the samples. These results suggest that S-IPN materials with desired physical properties may be synthesized by selecting one member of the network to have pronounced nonspherical charge distributions along its chains.

NASA Langley Research Center

Hampton, VA 23681-0001

August 14, 1996

\section{References}

1. Pater, Ruth H.: Interpenetrating Polymer Networks, High Performance. International Encyclopedia of Composites, Volume 2, Stuart M. Lee, ed., VCH Publ., 1990, pp. 377-401.

2. Pater, Ruth H.: Low Toxicity High Temperature PMR Polyimide. U.S. Pat. 5,171,822, Dec. 15, 1992.

3. St. Clair, Terry L.; and Progar, Donald J.: Polyimide Molding Powder, Coating, Adhesive and Matrix Resin. U.S. Pat. 5,147,966, Sept. 15, 1992.

4. Kirkegaard, P.; Pedersen, N. J.; and Eldrup, M.: PATFIT-88-A Data Processing System for Positron Annihilation Spectra on Mainframe and Personal Computers. RISO-M-2740, Risoe National Lab. (Denmark), 1989.

5. Nakanishi, $\mathrm{H}_{\text {; }}$ and Jean, Y. C.: Positrons and Positronium in Liquids. Positron and Positronium Chemistry, D. M. Schrader and Y. C. Jean, eds., Elsevier Science Publ. Co. Inc., 1988, pp. 159-192.

6. Hautojärvi, P., ed.: Positrons in Solids. Springer-Verlag, 1979.

7. Stevens, J. R.: Positron Annihilation. Polymers-Part A: Molecular Structure and Dynamics, Volume 16, R. A. Fava, ed., Academic Press, 1980, pp. 371-403.

8. Deng, Q.; Sundar, C. S.; and Jean, Y. C.: Pressure Dependence of Free-Volume Hole Properties in an Epoxy Polymer. J. Phys. Chem., vol. 96, 1992, pp. 492-495.

9. Eftekhari, A.; St. Clair, A. K.; Stoakley, D. M.; Sprinkle, Danny R.; and Singh, J. J.: Microstructural Characterization of Thin Polyimide Films by Positron Lifetime Spectroscopy. Polymers for Microelectronics-Resists and Dielectrics, Larry F. Thompson, C. Grant Willson, and Seiichi Tagawa, eds., ACS Symposium Series 537, 1994, pp. 537-545. 
Table I. Positron Lifetime Spectra in S-IPN Specimen

\begin{tabular}{|c|c|c|}
\hline $\begin{array}{c}\tau_{1} / I_{1}, \\
\text { psec/percent }\end{array}$ & $\begin{array}{c}\tau_{2} / I_{2}, \\
\text { psec/percent }\end{array}$ & $\begin{array}{c}\tau_{3} / I_{3}, \\
\text { psec/percent }\end{array}$ \\
\hline \multicolumn{3}{|c|}{100 percent LaRC ${ }^{\text {TM }}$-IA } \\
\hline $176 \pm 8 / 19.5 \pm 1.6$ & $488 \pm 3 / 80.0 \pm 2.0$ & $2165 \pm 181 / 0.50 \pm 0.06$ \\
\hline \multicolumn{3}{|c|}{50 percent LaRC ${ }^{\text {TM }}$-IA } \\
\hline $197 \pm 10 / 20.2 \pm 0.6$ & $394 \pm 1 / 79.4 \pm 0.6$ & $2285 \pm 216 / 0.40 \pm 0.07$ \\
\hline \multicolumn{2}{|c|}{0 percent LaRC ${ }^{\text {TM }}$-IA $(100$ percent LaRC } & TM - RP46) \\
\hline $195 \pm 9 / 18.2 \pm 2.1$ & $400 \pm 4 / 81.4 \pm 2.1$ & $2215 \pm 210 / 0.40 \pm 0.06$ \\
\hline
\end{tabular}

Table II. Free Volume Fractions $I_{2} V_{f_{2}}$ in S-IPN Samples

\begin{tabular}{|c|c|c|}
\hline $\begin{array}{c}\text { Resin system } \\
\text { LaRC }^{\text {TM }}-\text { RP46:LaRC }\end{array}$ & $I_{2} V_{f_{2}}$ \\
\hline $0: 100$ & $V_{f_{2}}\left(A^{3}\right)$ & $4.87 \pm 0.16$ \\
$25: 75$ & $6.08 \pm 0.20$ & $2.11 \pm 0.16$ \\
$35: 75$ & $2.72 \pm 0.21$ & $1.40 \pm 0.06$ \\
$50: 50$ & $1.77 \pm 0.15$ & $1.25 \pm 0.04$ \\
$65: 35$ & $1.58 \pm 0.04$ & $1.39 \pm 0.05$ \\
$75: 25$ & $1.82 \pm 0.05$ & $1.41 \pm 0.10$ \\
$100: 0$ & $1.77 \pm 0.12$ & $1.47 \pm 0.12$ \\
\hline
\end{tabular}

Table III. Density and Saturation Moisture Content of S-IPN Samples

\begin{tabular}{|c|c|c|c|}
\hline \multirow{2}{*}{$\begin{array}{c}\text { Resin system } \\
\text { LaRC }^{\mathrm{TM}} \text {-RP46:LaRC }\end{array}$} & \multicolumn{2}{|c|}{ Saturation moisture content } \\
\cline { 3 - 4 } & Density, $\mathrm{g} / \mathrm{cm}^{3}$ & w/o & v/o \\
\hline $0: 100$ & $1.3402 \pm 0.00299$ & 2.15 & 2.81 \\
$25: 75$ & $1.3815 \pm 0.00288$ & 1.69 & 2.28 \\
$35: 65$ & $1.3668 \pm 0.00200$ & 2.00 & 2.66 \\
$50: 50$ & $1.3713 \pm 0.00411$ & 2.39 & 3.17 \\
$65: 35$ & $1.3629 \pm 0.00326$ & 1.93 & 2.56 \\
$75: 25$ & $1.3546 \pm 0.00368$ & 2.18 & 2.87 \\
$100: 0$ & $1.3572 \pm 0.00200$ & 2.75 & 3.60 \\
\hline
\end{tabular}


Table IV. Free Volume Fraction and Dielectric Constant of S-IPN Samples

\begin{tabular}{|c|c|c|c|}
\hline $\begin{array}{c}\text { Resin system } \\
\text { LaRC }^{\mathrm{TM}} \text {-RP46:LaRC }\end{array}$ & $\begin{array}{c}\text { Free volume fraction, } \\
f, \text { percent }\end{array}$ & $\begin{array}{c}\text { Dielectric constant, } \\
C d\end{array}$ & ${ }^{*} C d\left(\frac{4 \pi}{A}\right)$ \\
\hline $0: 100$ & $2.81 \pm 0.09$ & $8.00 \pm 2 \%$ & $2.85 \pm 2 \%$ \\
$25: 75$ & $1.22 \pm 0.09$ & $8.55 \pm 2 \%$ & $3.04 \pm 2 \%$ \\
$35: 65$ & $0.79 \pm 0.06$ & $8.84 \pm 2 \%$ & $3.11 \pm 2 \%$ \\
$50: 50$ & $0.73 \pm 0.06$ & $8.84 \pm 2 \%$ & $3.13 \pm 2 \%$ \\
$65: 35$ & $0.81 \pm 0.02$ & $8.99 \pm 2 \%$ & $3.16 \pm 2 \%$ \\
$75: 25$ & $0.82 \pm 0.02$ & $8.89 \pm 2 \%$ & $3.13 \pm 2 \%$ \\
$100: 0$ & $0.85 \pm 0.06$ & $8.90 \pm 2 \%$ & $3.13 \pm 2 \%$ \\
\hline
\end{tabular}

${ }^{*} \varepsilon_{\text {exp }}=C d\left(\frac{4 \pi}{A}\right)=C d(0.352)$.

Table V. Experimental and Computed Values of Dielectric Constants of S-IPN Samples

$$
\left[\varepsilon_{R}=3.18\right]
$$

\begin{tabular}{|c|c|c|c|c|}
\hline & \multirow{2}{*}{$\begin{array}{c}\text { Resin system } \\
\text { Sample }\end{array}$} & Free volume fraction & \multicolumn{2}{|c|}{ Dielectric constant } \\
\cline { 3 - 5 } & LaRC $^{\mathrm{TM}}-$ RP46:LaRC & $\varepsilon_{\text {exp }}$ & ${ }^{*} \varepsilon_{\text {comp }}$ \\
\hline 1 & $0: 100$ & $2.81 \pm 0.09$ & $2.85 \pm 2 \%$ & $2.99 \pm 2 \%$ \\
2 & $25: 75$ & $1.22 \pm 0.09$ & $3.04 \pm 2 \%$ & $3.09 \pm 2 \%$ \\
3 & $35: 65$ & $0.79 \pm 0.06$ & $3.11 \pm 2 \%$ & $3.13 \pm 2 \%$ \\
4 & $50: 50$ & $0.73 \pm 0.02$ & $3.13 \pm 2 \%$ & $3.13 \pm 2 \%$ \\
5 & $65: 35$ & $0.81 \pm 0.02$ & $3.16 \pm 2 \%$ & $3.13 \pm 2 \%$ \\
6 & $75: 25$ & $0.82 \pm 0.05$ & $3.13 \pm 2 \%$ & $3.12 \pm 2 \%$ \\
7 & $100: 0$ & $0.85 \pm 0.06$ & $3.13 \pm 2 \%$ & $3.12 \pm 2 \%$ \\
\hline
\end{tabular}

$* \varepsilon_{\mathrm{comp}}=\left(\frac{1-f}{\varepsilon_{R}}+\frac{f}{\varepsilon_{\mathrm{air}}}\right)^{-1}$.

Table VI. Experimental and Computed Values of Densities of S-IPN Samples

$$
[\alpha=0.0168 \pm 0.0031]
$$

\begin{tabular}{|c|c|c|}
\hline $\begin{array}{c}\text { Resin system } \\
\text { LaRC }^{\text {TM }} \text {-RP46:LaRC }\end{array}$-IA & $\rho_{\text {exp }}, \mathrm{g} / \mathrm{cm}^{3}$ & $\rho_{\text {comp }}, \mathrm{g}^{3} \mathrm{~cm}^{3}$ \\
\hline $0: 100$ & $1.3402 \pm 0.0029$ & $1.3402 \pm 0.0029$ \\
$25: 75$ & $1.3815 \pm 0.0028$ & $1.3559 \pm 0.0020$ \\
$35: 65$ & $1.3668 \pm 0.0020$ & $1.3620 \pm 0.0028$ \\
$50: 50$ & $1.3713 \pm 0.0041$ & $1.3713 \pm 0.0041$ \\
$65: 35$ & $1.3629 \pm 0.0032$ & $1.3671 \pm 0.0028$ \\
$75: 25$ & $1.3546 \pm 0.0036$ & $1.3644 \pm 0.0020$ \\
$100: 0$ & $1.3572 \pm 0.0020$ & $1.3572 \pm 0.0020$ \\
\hline
\end{tabular}




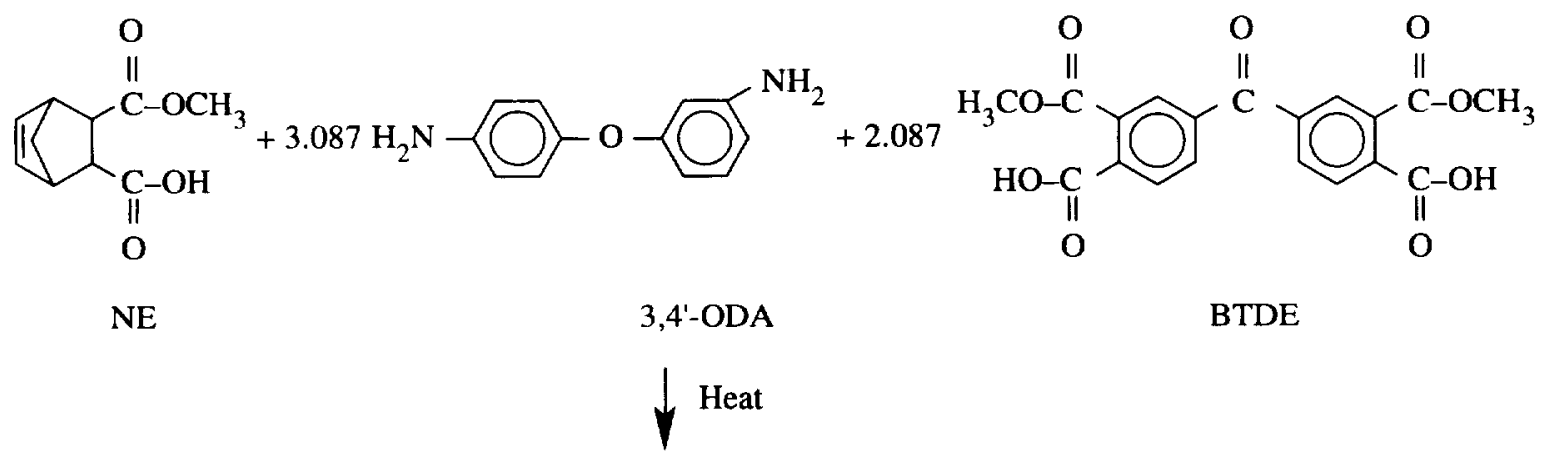

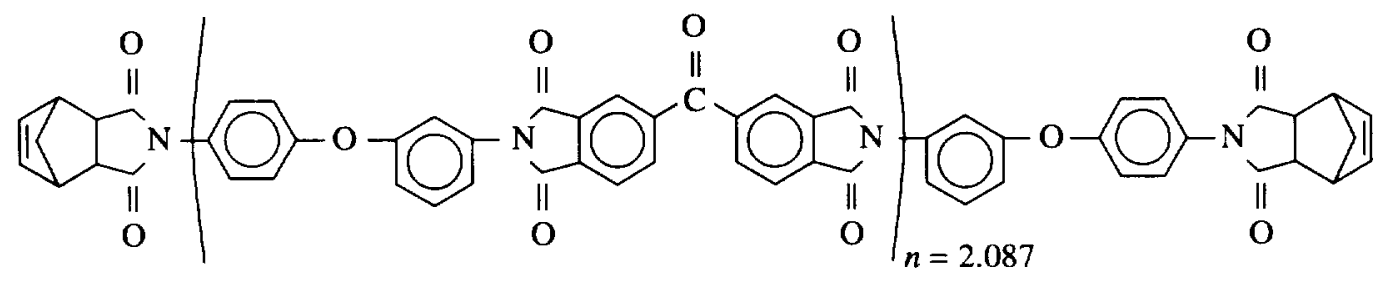

Uncross-linked LaRC ${ }^{\mathrm{TM}}$-RP46

Figure 1. Synthesis of $\mathrm{LaRC}^{\mathrm{TM}}-\mathrm{RP} 46$ polyimide.<smiles>Nc1cccc(Oc2cccc(N)c2)c1</smiles>

ODPA

3,4'-ODA

PA $30 \%$ solid in NMP

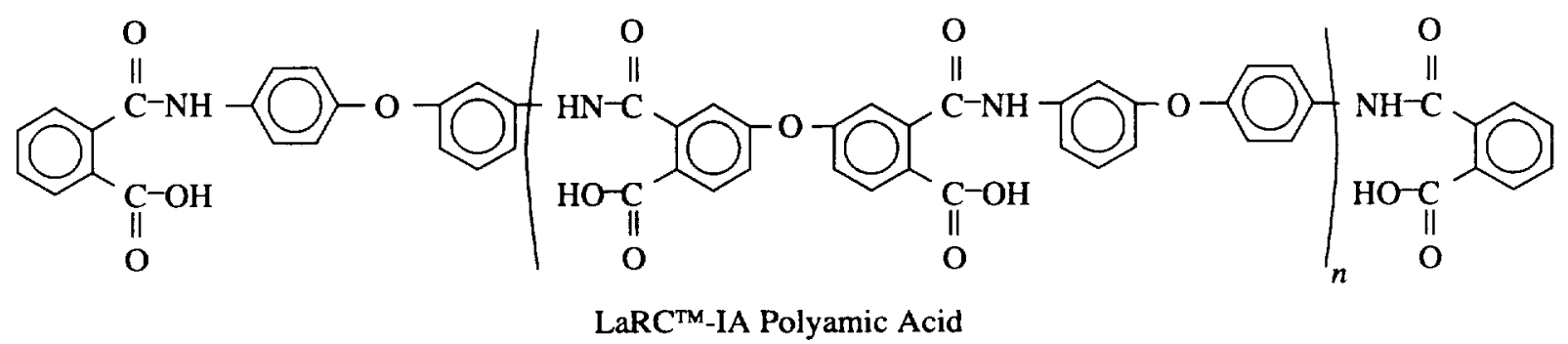

Figure 2. Synthesis of LaRC ${ }^{\text {TM }}$-IA polyamic acid. 


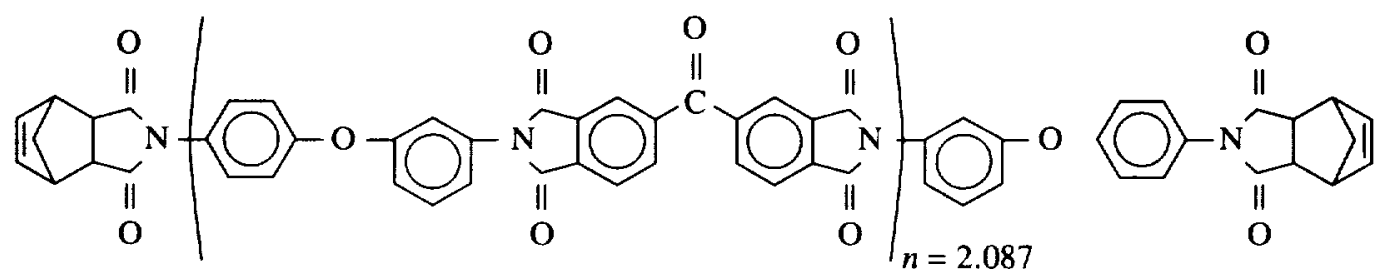

Uncross-linked LaRC ${ }^{\mathrm{TM}}-\mathrm{RP} 46$

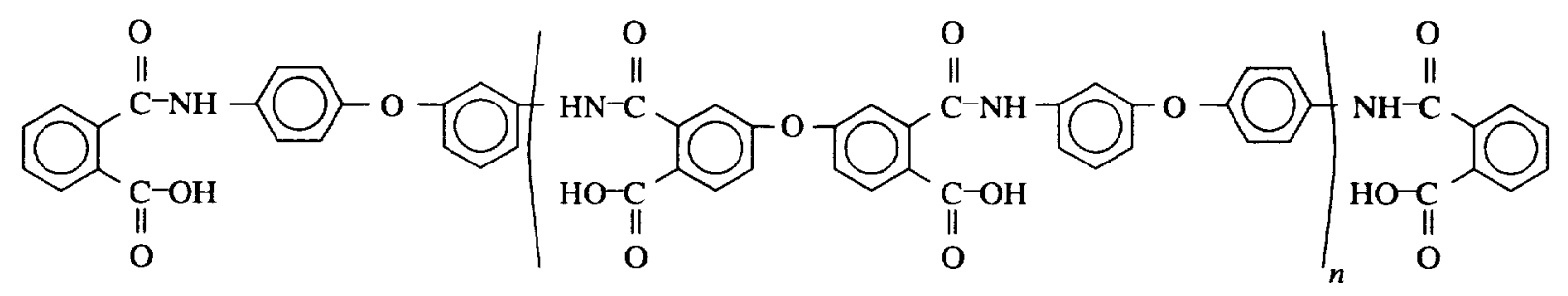

LaRC ${ }^{\text {TM}}-$ IA Polyamic Acid

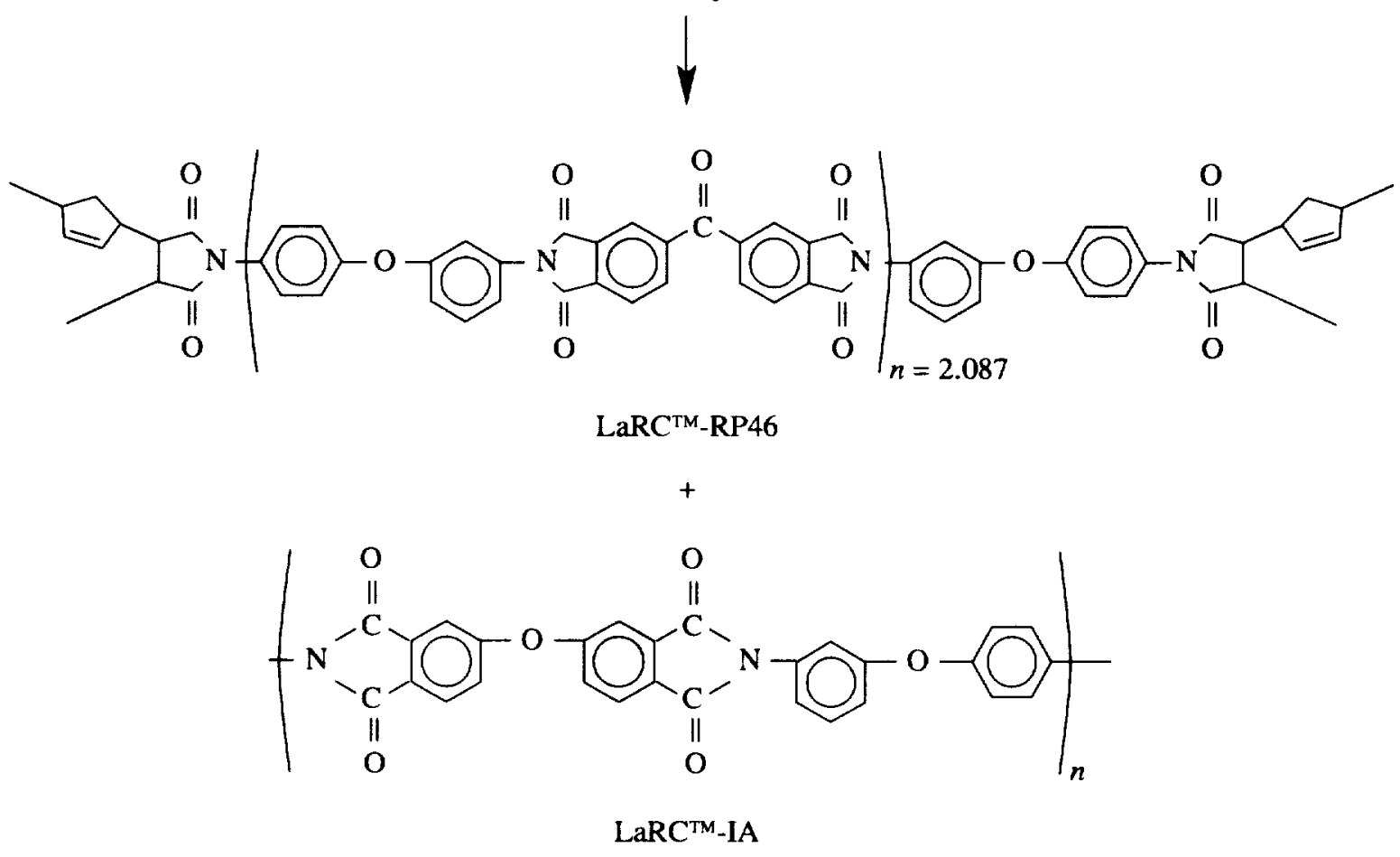

LaRC TM-RP46/LaRC TM-IA Semi-2-IPN

(a) Synthesis of $\mathrm{LaRC}^{\mathrm{TM}}-\mathrm{RP} 46 / \mathrm{LaRC} \mathrm{TM}^{\mathrm{TM}} \mathrm{IA}$.

Figure 3. Synthesis of Semi-Interpenetrating Polymer Network. 


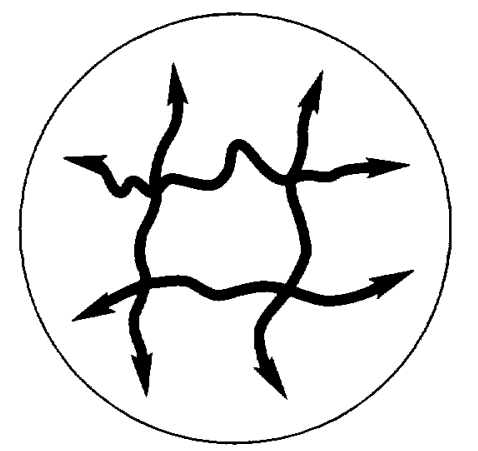

Addition type thermosetting polyimide

- Easy to process

- Brittle

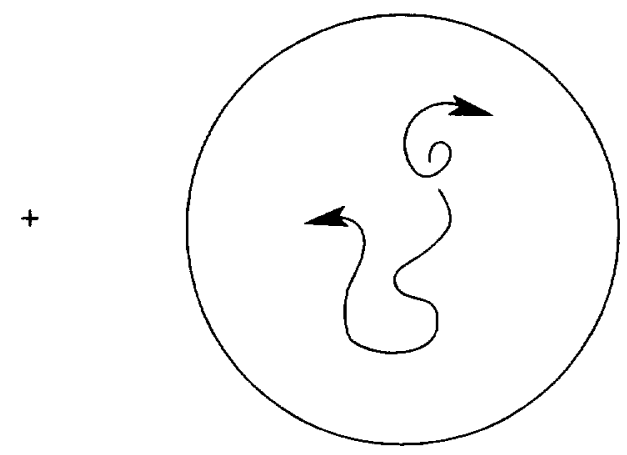

Condensation type thermoplastic polyimide

- Difficult to process

- Tough

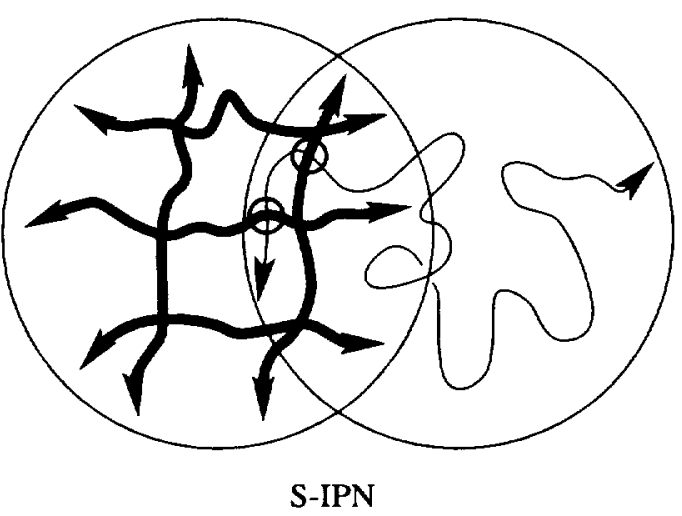

- Easy to process

- Tough

(b) Concept of mutual interpenetration of constituent polymers.

Figure 3. Concluded. 


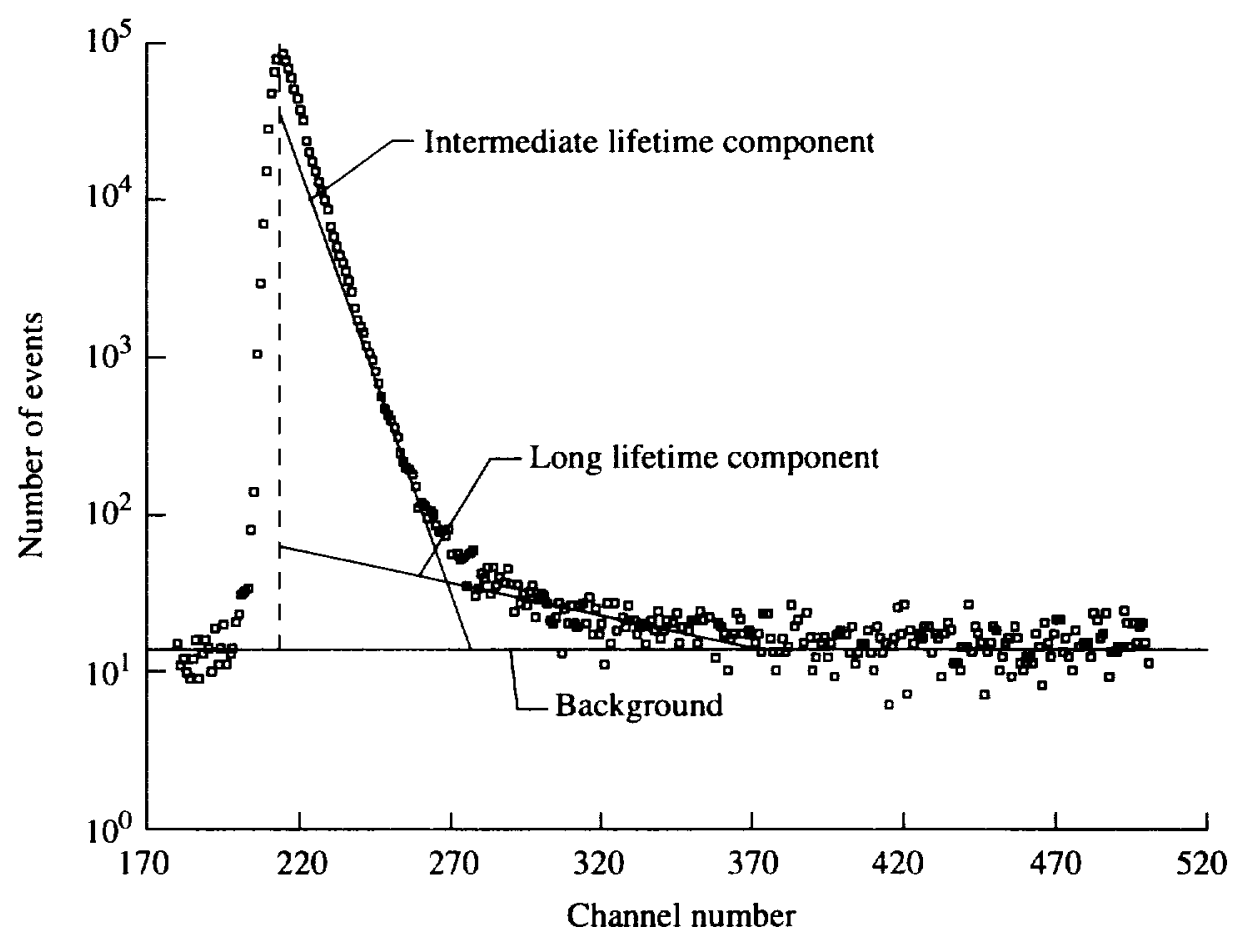

Figure 4. Typical positron lifetime spectrum in $\mathrm{LaRC}^{\mathrm{TM}}$-IA thermoplastic polyimide. 1 channel $=25.6$ psec.

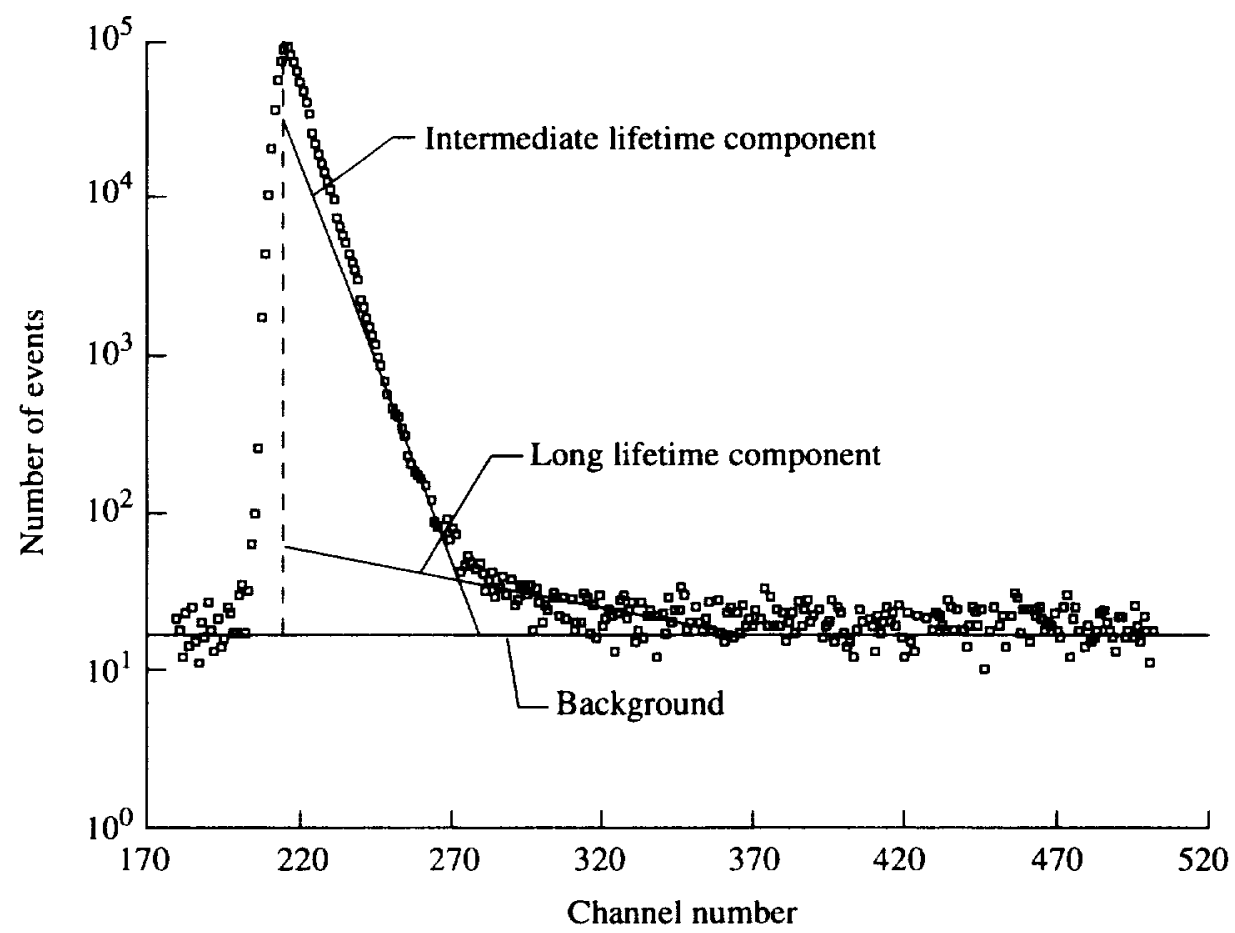

Figure 5. Typical positron lifetime spectrum in 50:50 mixture of $\mathrm{LaRC}^{\mathrm{TM}}-\mathrm{RP} 46$ and $\mathrm{LaRC}^{\mathrm{TM}}-\mathrm{IA}$ polyimides. $1 \mathrm{channel}=25.6 \mathrm{psec}$. 


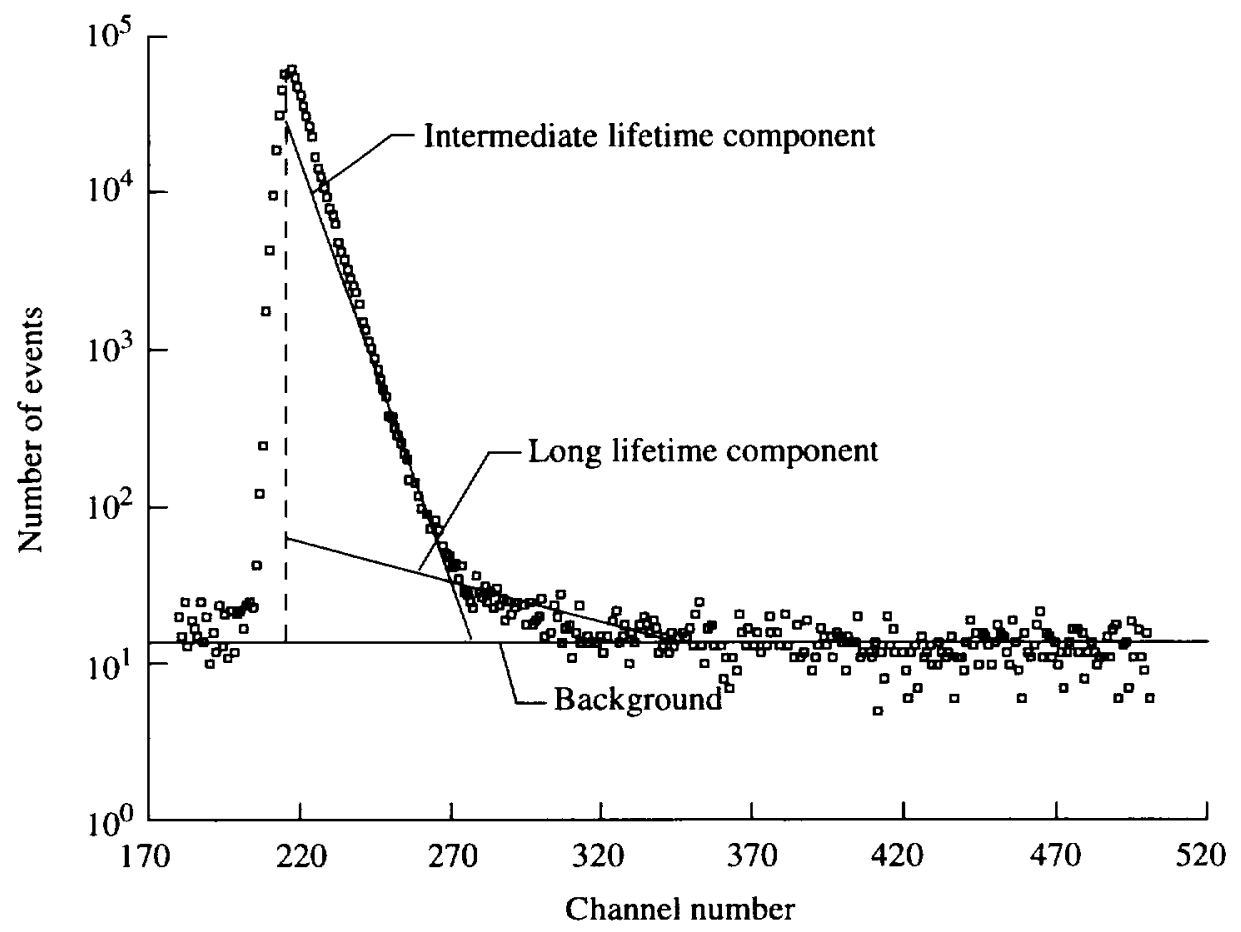

Figure 6. Typical positron lifetime spectrum in $\mathrm{LaRC}^{\mathrm{TM}}-\mathrm{RP} 46$ thermoset polyimide. 1 channel $=25.6 \mathrm{psec}$.

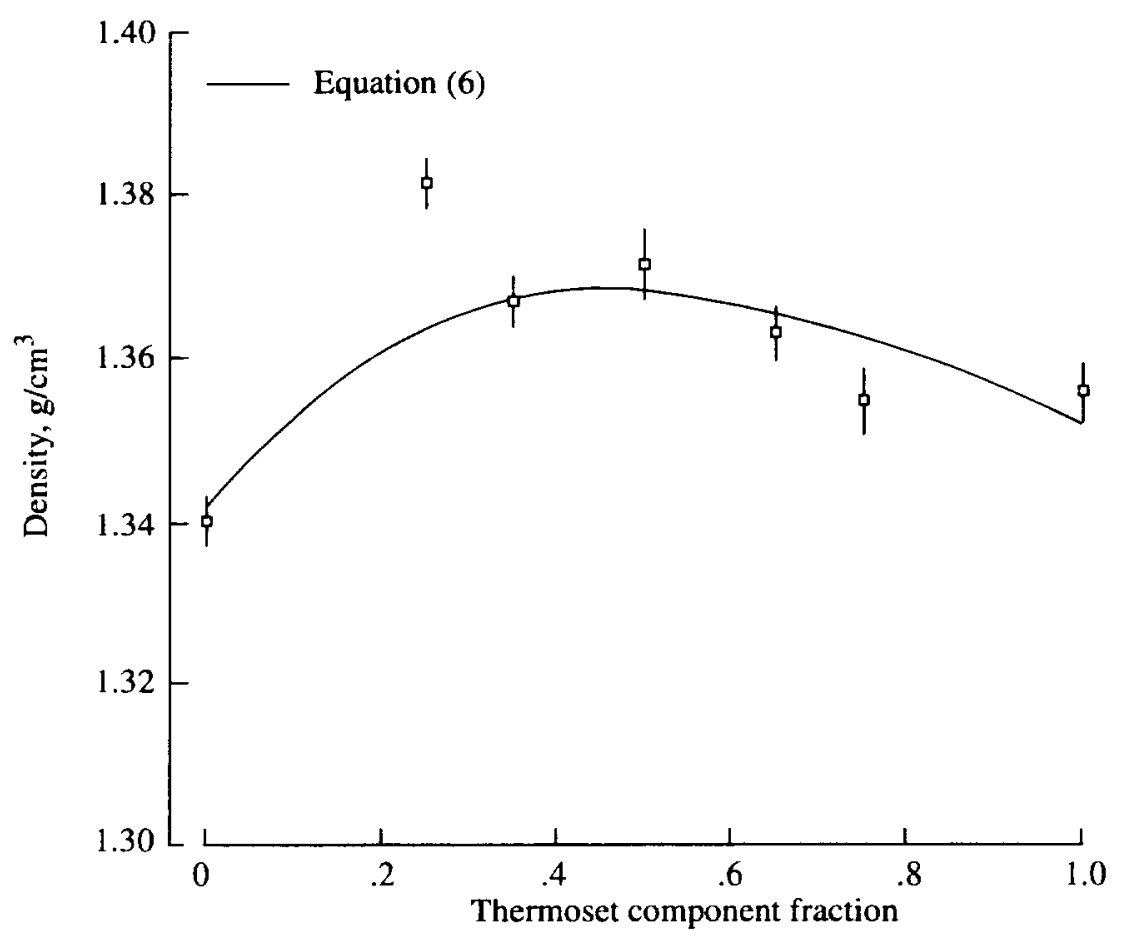

Figure 7. Density versus concentration of thermoset component in S-IPN samples. 


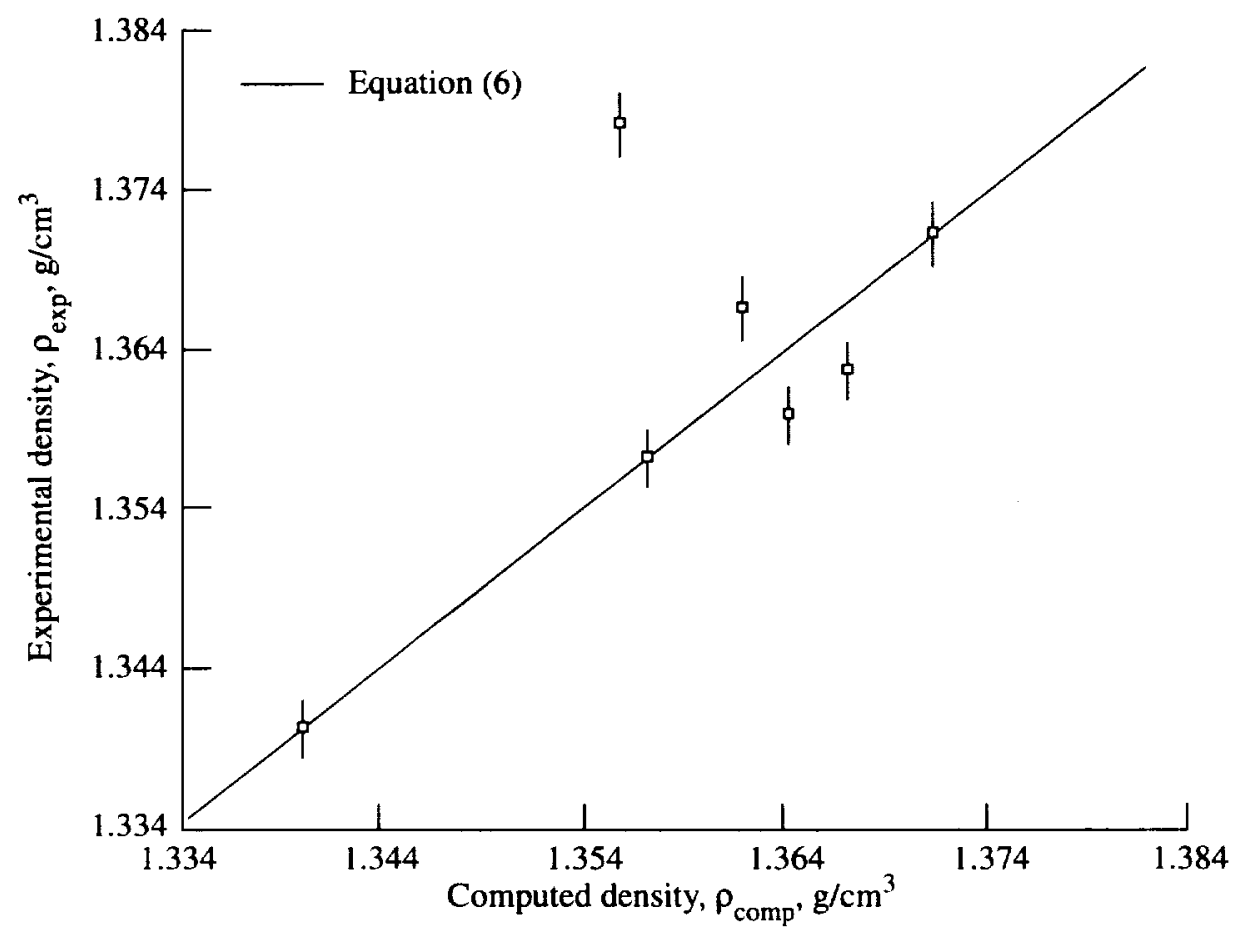

Figure 8. Comparison between experimental and computed values of densities of S-IPN samples.

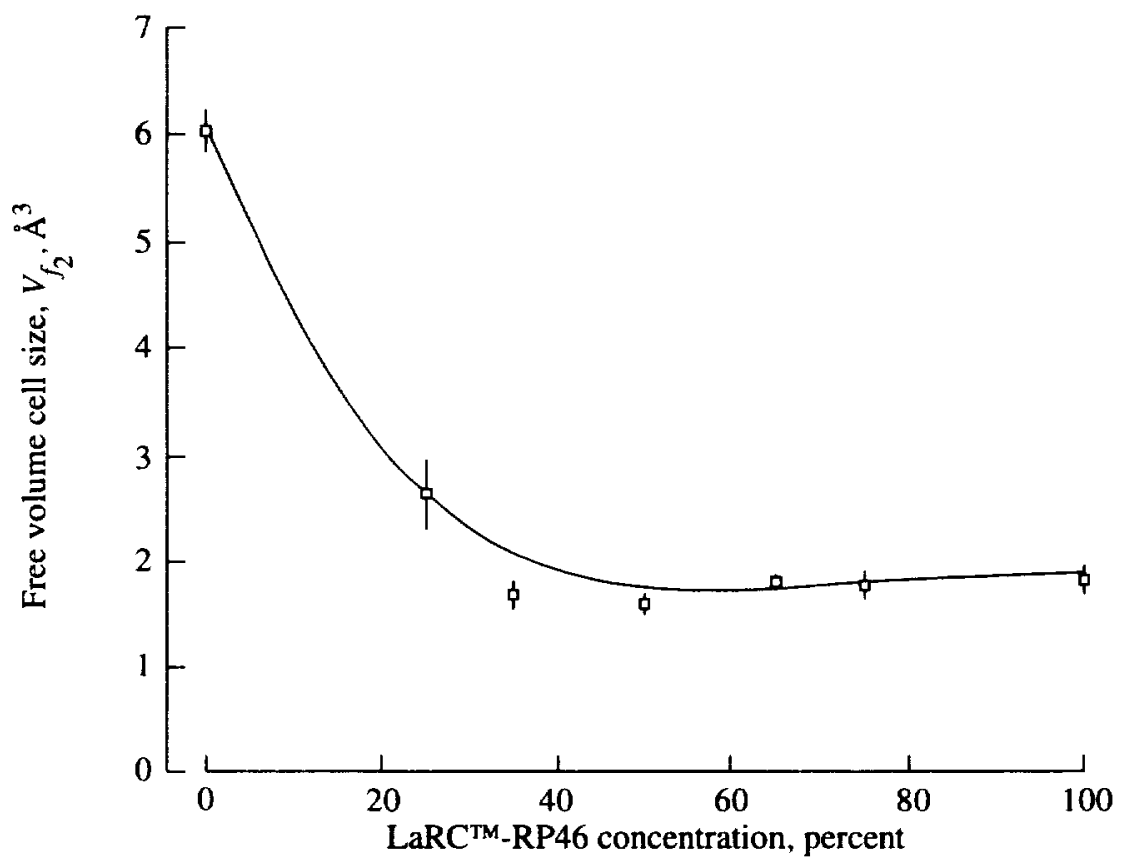

Figure 9. Free volume cell size versus concentration of thermoset component in S-IPN samples. 


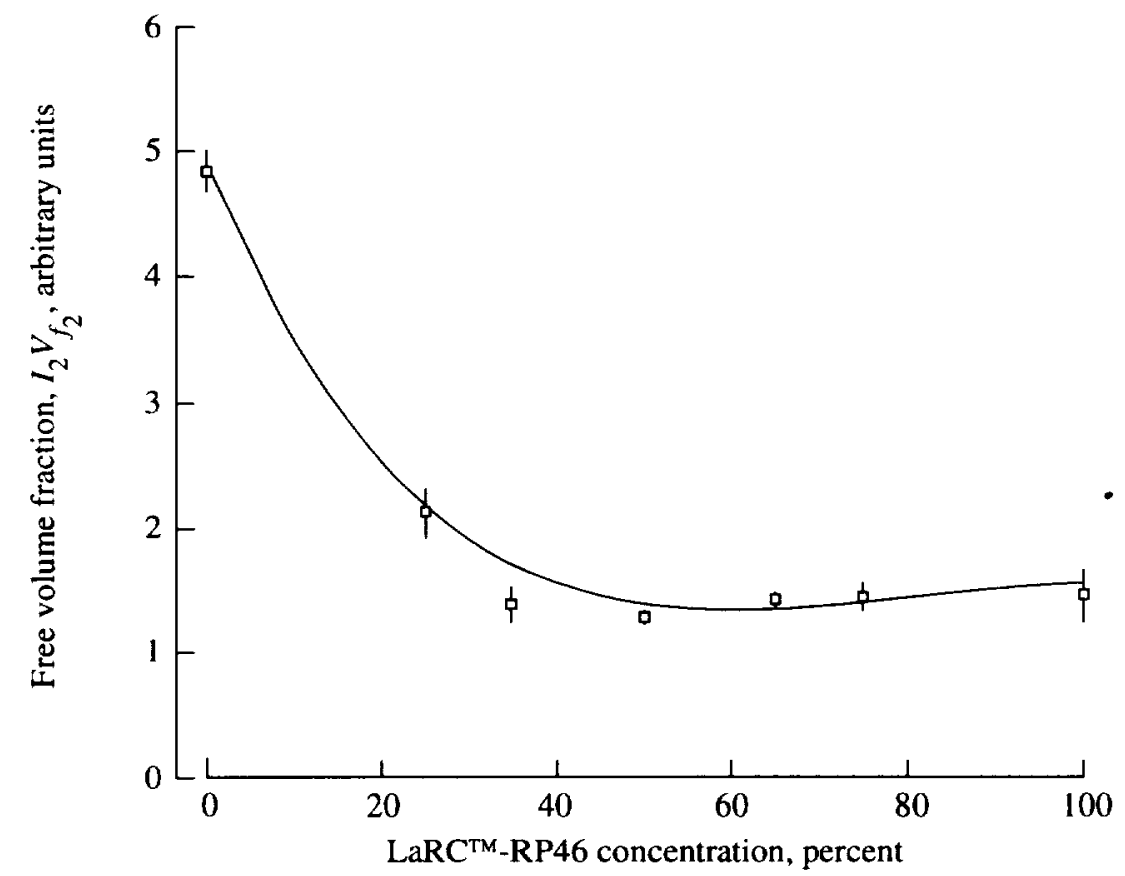

Figure 10. Free volume fraction versus concentration of thermoset component in S-IPN samples.

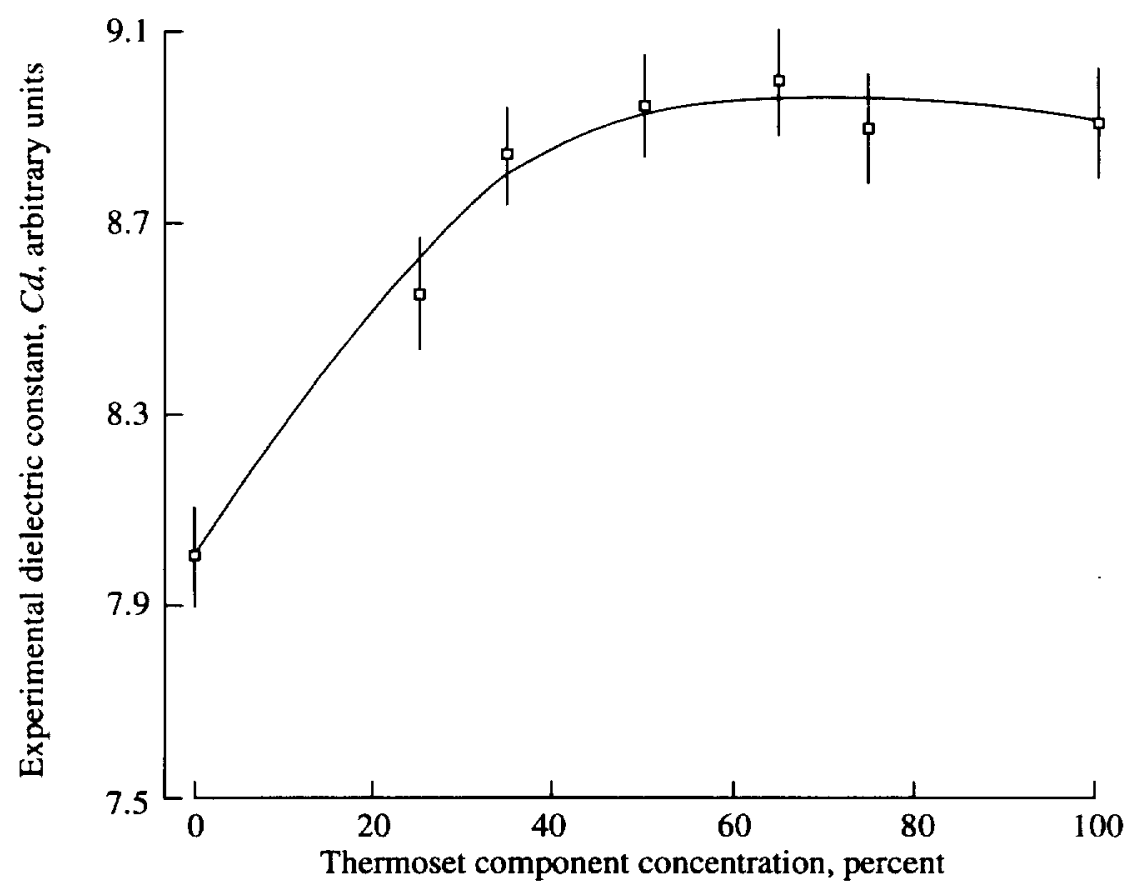

Figure 11. Dielectric constant versus concentration of thermoset component in S-IPN samples. 


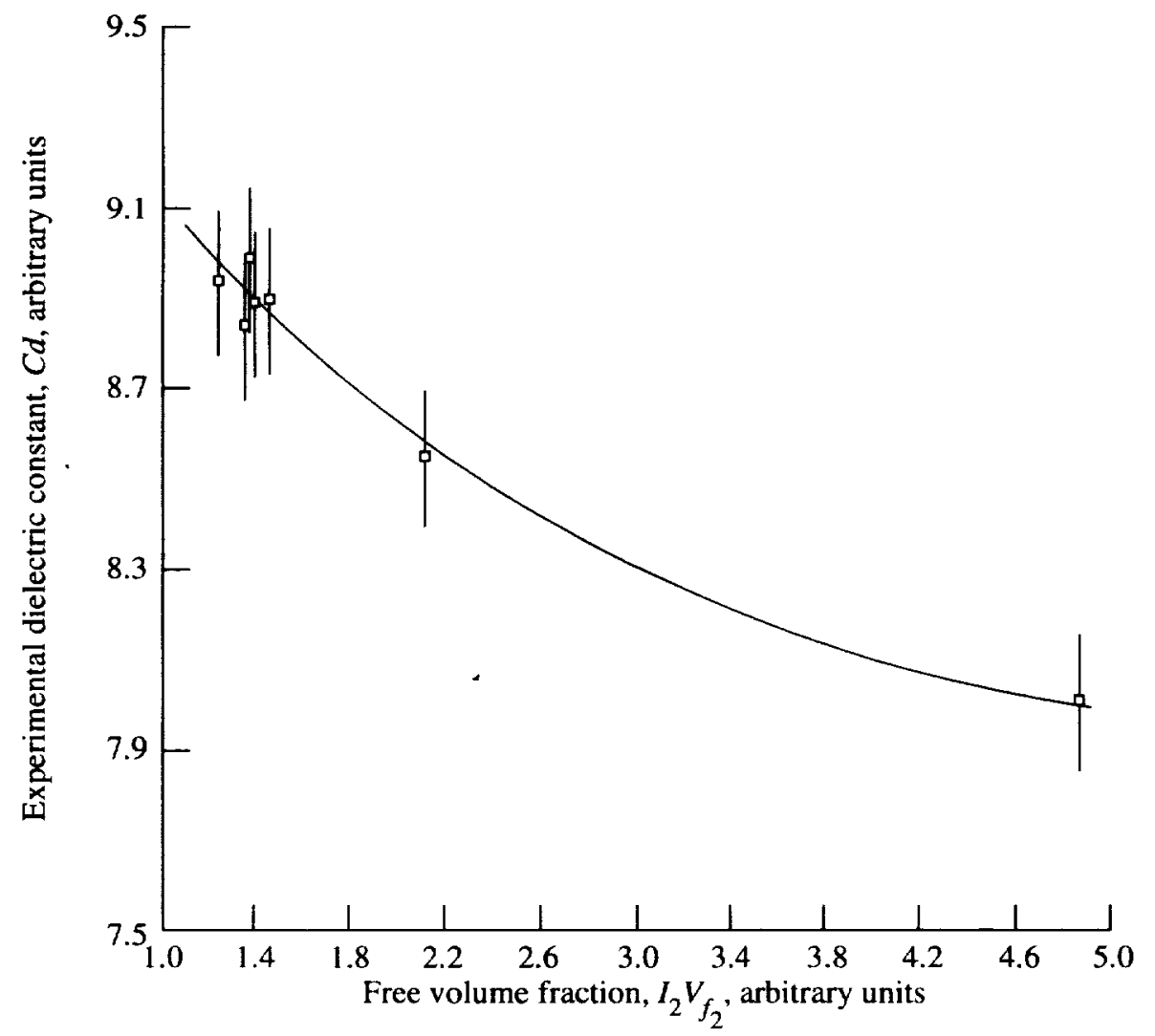

Figure 12. Experimental dielectric constant versus free volume fraction in S-IPN samples.

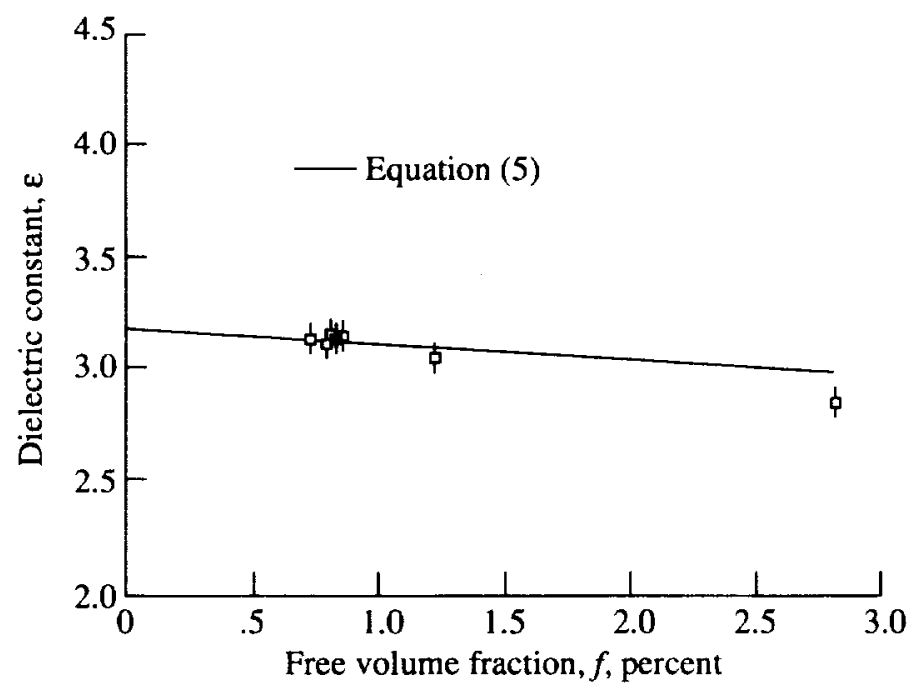

Figure 13. Dielectric constant versus free volume fraction in S-IPN samples. 



\begin{tabular}{|c|c|c|c|}
\hline \multicolumn{3}{|c|}{ REPORT DOCUMENTATION PAGE } & $\begin{array}{l}\text { Form Approved } \\
\text { OMB No. 0704-0188 }\end{array}$ \\
\hline \multicolumn{4}{|c|}{ 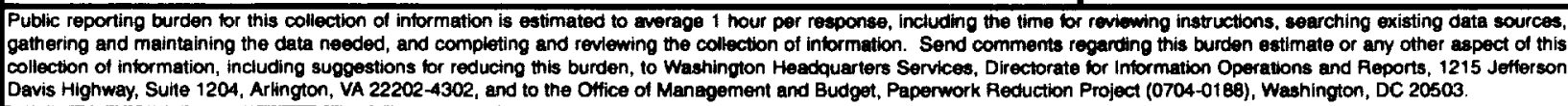 } \\
\hline 1. AGENCY USE ONLY (Leave blank) & $\begin{array}{l}\text { 2. REPOFT DATE } \\
\text { October } 1996\end{array}$ & \multicolumn{2}{|c|}{$\begin{array}{l}\text { 3. REPOAT TYPE AND DATES COVEAED } \\
\text { Technical Paper }\end{array}$} \\
\hline \multicolumn{3}{|c|}{$\begin{array}{l}\text { 4. TITLE AND SUBTITLE } \\
\text { Microstructural Characterization of Semi-Interpenetrating Polymer } \\
\text { Networks by Positron Lifetime Spectroscopy }\end{array}$} & \multirow[t]{2}{*}{$\begin{array}{l}\text { 5. FUNDING NUMBERS } \\
\text { WU 505-63-50-01 }\end{array}$} \\
\hline \multicolumn{3}{|c|}{$\begin{array}{l}\text { 6. AUTHOR(S) } \\
\text { Jag J. Singh, Ruth H. Pater, and Abe Eftekhari }\end{array}$} & \\
\hline \multicolumn{3}{|c|}{ 7. PEEFFORIMING ORGANIZATIONINAME(S) AND ADDFESS(ES) } & $\begin{array}{l}\text { 9. PERFOAMING ORGANIZATION } \\
\text { REPORT NUMBER } \\
\text { L- } 17576\end{array}$ \\
\hline \multicolumn{3}{|c|}{$\begin{array}{l}\text { 9. SPONSORINGMONITORING AGENCY NAME(S) AND ADDRESS(ES) } \\
\text { National Aeronautics and Space Administration } \\
\text { Washington, DC 20546-0001 }\end{array}$} & $\begin{array}{l}\text { 10. SPONSORINGMONTORING } \\
\text { AGENCY REPORT NUMBER } \\
\text { NASA TP-3617 }\end{array}$ \\
\hline \multicolumn{4}{|c|}{$\begin{array}{l}\text { 11. SUPPLEMENTAFY NOTES } \\
\text { Singh and Pater: Langley Research Center, Hampton, VA; Eftekhari: Hampton University, Hampton, VA. }\end{array}$} \\
\hline \multicolumn{2}{|c|}{$\begin{array}{l}\text { 12a. DISTRIBUTIONAVAILABILITY STATEMENT } \\
\text { Unclassified-Unlimited } \\
\text { Subject Category } 35 \\
\text { Availability: NASA CASI (301) 621-0390 }\end{array}$} & 12b. DISTRI & 12b. DISTRIBUTION CODE \\
\hline \multicolumn{4}{|c|}{$\begin{array}{l}\text { 13. ABSTRACT (Maximum } 200 \text { words) } \\
\text { Thermoset and thermoplastic polyimides have complementary physical and mechanical properties. Whereas ther- } \\
\text { moset polyimides are brittle and generally easier to process, thermoplastic polyimides are tough but harder to pro- } \\
\text { cess. A combination of these two types of polyimides may help produce polymers more suitable for aerospace } \\
\text { applications. Semi-Interpenetrating Polymer Networks (S-IPN) of thermoset LaRC TM-RP46 and thermoplastic } \\
\text { LaRC }{ }_{\text {TM }} \text {-IA polyimides were prepared in weight percent ratios ranging from 100:0 to } 0: 100 \text {. Positron lifetime } \\
\text { measurements were made in these samples to correlate their free volume features with physical and mechanical } \\
\text { properties. As expected, positronium atoms are not formed in these samples. The second lifetime component has } \\
\text { been used to infer the positron trap dimensions. The "free volume" goes through a minimum at a ratio of about } \\
\text { 50:50, and this suggests that S-IPN samples are not merely solid solutions of the two polymers. These data and } \\
\text { related structural properties of the S-IPN samples are discussed. }\end{array}$} \\
\hline \multirow{2}{*}{\multicolumn{3}{|c|}{$\begin{array}{l}\text { 14. SUBJECT TEAMS } \\
\text { Polyimides (thermoset and thermoplastic); Semi-interpenetrating polymer networks; } \\
\text { Positron lifetime spectroscopy; Free volume cell radius; Free volume fraction; } \\
\text { Dielectric constant; Electric dipole interactions }\end{array}$}} & $\begin{array}{l}\text { 15. NUMBER OF PAGES } \\
17\end{array}$ \\
\hline & & & $\begin{array}{r}\text { 16. PAICE CODE } \\
\text { A03 }\end{array}$ \\
\hline $\begin{array}{l}\text { 17. SECURITY CLASSIFICATION } \\
\text { OF REPORT } \\
\text { Unclassified }\end{array}$ & $\begin{array}{l}\text { 18. SECURITY CLASSIFICATION } \\
\text { OF THIS PAGE } \\
\text { Unclassified }\end{array}$ & $\begin{array}{l}\text { 19. SECURTTY CLASSIFICATION } \\
\text { OF ABSTRACT } \\
\text { Unclassified }\end{array}$ & $\begin{array}{l}\text { 20. LIMTTATION } \\
\text { OF ABSTRACT }\end{array}$ \\
\hline NSN 7540-01-280-5500 & & & $\begin{array}{l}\text { Standard Form } 298 \text { (Rev. 2-89) } \\
\text { Prescribed by ANSI Std. Z39-18 } \\
298-102\end{array}$ \\
\hline
\end{tabular}

